\title{
The context of the impact of the COVID-19 contingency in establishments with foreign trade operations
}

\section{El contexto del impacto de la contingencia COVID-19 en los establecimientos con operaciones en comercio exterior}

\author{
CARMONA-GARCÍA, Nélida*†, RAMÍREZ-BARAJAS, Alejandro and ALMANZA-SERRANO, Ma. \\ Leticia
}

Universidad Tecnológica del Suroeste de Guanajuato, Mexico.

ID $1^{\text {st }}$ Author: Nélida, Carmona-García / ORC ID: 0000-0003-0850-3668, Researcher ID Thomson: S-8608-2018, CVU CONACYT ID: 229857

ID $1^{\text {st }}$ Co-author: Alejandro, Ramírez-Barajas / ORC ID: 0000-0002-8426-3267, Researcher ID Thomson: S-8634-2018, CVU CONACYT ID: 228229

ID $2^{\text {nd }}$ Co-author: Ma. Leticia, Almanza-Serrano / ORC ID: 0000-0002-1481-5716, Researcher ID Thomson: S-8647-2018, CVU CONACYT ID: 230006

DOI: $10.35429 / J I E C .2020 .7 .4 .1 .6$

Received July 10, 2020; Accepted December 30, 2020

\begin{abstract}
The general objective is to be able to know the impact that has been generated in the establishments with operations in foreign trade derived from the contingency COVID-19. Therefore, the review is done from the perspective of knowing the state of Mexican and Guanajuato companies that have foreign trade as an activity, which sector they belong to, which of them manage foreign trade programs such as IMMEX, and that it is important to highlight their impact as well. On the other hand, important data such as the results of the National Institute of Statistics and Geography (INEGI) are considered, such as the fact that $17 \%$ of the economic units in Mexico with international trade transactions are macro companies and concentrate $82 \%$ of the value of foreign trade of manufacturing companies, just as foreign trade represents approximately $65 \%$ of the GDP and exports about $30 \%$ in recent years. Therefore, it is concluded that the pandemic achieved great changes by which, Mexicans instead of taking it as an economic stoppage, quickly took it as an opportunity to create micro-enterprises achieving in this way opportunities, as well; it changed the way countries relate to each other and how governments face the problem on a daily basis, but it can be stated that neither international trade nor foreign trade stops, because they are part of an activity that determines the survival of world economies and without which life today could not be conceived. In this way, it is expected that in the following years; products will be exported to different countries, generating an increase in wealth within Mexico, as has been shown in the last semester of 2020 with the increase of Mexican exports.
\end{abstract}

\begin{abstract}
Resumen
En un argumento de revisión de la literatura y el estudio del estado del arte, se presenta el siguiente trabajo, en el cual se contextualiza la afectación de la contingencia actual que se vive en el mundo, como lo es el COVID-19. El objetivo general es poder conocer el impacto que se ha generado en los establecimientos con operaciones en comercio exterior derivado de la contingencia COVID-19. Por ello, se hace la revisión desde la perspectiva de conocer el estado de las empresas mexicanas y Guanajuatenses que tienen como actividad el comercio exterior, a qué sector pertenecen, cuáles de ellas manejan programas de comercio exterior como el IMMEX, y que es importante destacar su impacto también. Por otro lado, se consideran datos importantes como los resultados que arroja el Instituto Nacional de Estadística y Geografía (INEGI), tales como que el 17\% de las unidades económicas en México con transacciones comerciales internacionales son macroempresas y concentran el $82 \%$ del valor del comercio exterior de las empresas manufactureras, al igual que el comercio exterior representa aproximadamente el $65 \%$ del PIB y las exportaciones cerca del $30 \%$ en los últimos años. Por lo anterior, se concluye que la pandemia consiguió grandes cambios por los cuales, los mexicanos en vez de tomarlo como un paro económico, rápidamente lo tomaron como una oportunidad para crear microempresas logrando de esta manera oportunidades, al igual; cambio la forma en la que se relacionan los países y en cómo los gobiernos enfrentan la problemática día a día, pero se puede afirmar que ni el comercio internacional, ni el comercio exterior se detienen, por formar parte de una actividad que determina la supervivencia de las economías mundiales y sin las cuales no se podría concebir la vida actual. De esta manera se espera que, para los siguientes años; los productos logren ser exportados a diferentes países, generando incrementar la riqueza dentro de México, como se ha estado manifestando en el último semestre de 2020 con el aumento de las exportaciones mexicanas.
\end{abstract}

Empresas, Comercio exterior, IMMEX, COVID-19

Citation: CARMONA-GARCÍA, Nélida, RAMÍREZ-BARAJAS, Alejandro and ALMANZA-SERRANO, Ma. Leticia. The context of the impact of the COVID-19 contingency in establishments with foreign trade operations. RINOE JournalInternational Economy. 2020. 4-7:1-6.

\footnotetext{
* Correspondence to Author (Email: ncarmona@utsoe.edu.mx)

$\dagger$ Researcher contributing first Author.
} 


\section{Introduction}

Faced with the pandemic that has occurred worldwide due to the presence of COVID-19, an unprecedented crisis has been marked within the international economy; This health contingency will have very strong effects from the economic point of view, and in which Mexico may be affected even in its foreign trade operations. Although it is true, exports in the first semester of this year (2020) have increased according to the Trade Balance for the month of June (INEGI, 2020), it is asserted that in Mexico exports will fall to the minimum this year, but they will recover in the same proportion in 2021, so that, if the forecast is correct; It would mean that Mexico would be among those that make up the T-MEC block, the first to recover.

The main objective of this work is to publicize the impact that the COVID-19 contingency has generated mainly in Mexican establishments or companies, highlighting those located in the state of Guanajuato, taking into account the operations that come to be carried out in foreign trade matters. , and the effects that have occurred since the beginning of this year (2020). To this end, the panorama of those foreign trade companies is presented, without distinction of sector; that have been affected or vulnerable, since the beginning of the contingency in Mexico, in such a way that data can be obtained that contribute to propose strategies that help to mitigate said affectations.

Data from primary sources such as the Ministry of the Economy will be examined, and that, through INEGI, offer a visualization of trade balances in comparison with previous years, in order to understand the impact of COVID-19 and, even more importantly, provide elements to adopt a positive and responsive position to the present and future threats that this situation could generate in foreign trade. On the other hand, the degree and percentage of affectation that this contingency brings with it is also considered, to take into account what it consists of, how it spreads and what repercussions it brings, both for people, but especially in this case to the companies of the state of Guanajuato.
It is important to note that the United States of North America is Mexico's most important commercial partner, and also one of the countries most affected by COVID-19, therefore, in the midst of the pandemic; the TMEC came into force which, together with Canada, comes to replace NAFTA; a circumstance that is expected to allow the reactivation of foreign trade between these countries.

Faced with the pandemic, the WTO (World Trade Organization) foresees that the shipment of merchandise will fall a very high percentage this year, which will affect internationally, and even more so in Mexico, mainly the state of Guanajuato; since there are large companies that are dedicated to foreign trade installed.

\section{Context}

\section{Foreign trade}

Foreign trade is defined by the WHO, the international trade and commercial exchange of a country when the target market for this transaction is specified. It is also defined as: "the set of legal systems, national and international, that regulate the necessary relationships on this matter. They exist between public bodies in different states and for individuals who carry out acts classified as foreign trade".

Historically, the nation's foreign trade is linked to the physical transactions of products and merchandise. At present, they are also included comes of various types, services, technology and human resources. For a country, foreign trade can be seen as an economic development strategy.

Foreign trade is generally subject to various regulations for both product control (health, safety, etc.), as well as procedures (bureaucratic procedures, records, etc.) and taxation (taxes, tariffs, etc.). 


\section{Exports}

According to the World Trade Organization (WTO), exports consist of obtaining profits from the sale of products and services to other countries. Hence, sellers (exporters) enjoy the privilege of having clients outside their borders (importers), and of course, the rules applicable to the target market in question must be taken into account.

In general, according to economic points of view, exports generate income for the selling country, so they are a source of wealth. In addition, export is a way of entering international markets, being one of the most common ways for various companies.

\section{Indirect export.}

It occurs when a producer is sold to a national client, who in turn delivers to sell abroad. The most common national client in this type of export is the trading company.

\section{Direct export.}

It occurs when the company sells to a foreign buyer, taking care of logistics activities such as: export duties, transportation, packaging, cargo, agent, documents, including also getting the customer. The responsibility for the merchandise and the costs incurred is defined by the agreement of the causal trade term between the exporter and the importer, called "Incoterm".

In April 2020, the value of merchandise exports reached 23.385 million dollars, a figure made up of 22.627 million dollars of non-oil exports and 758 million dollars of oil companies. Thus, in the reference month, total exports showed an annual decline of (-) 40.9\%, which was the result of contractions of (-) $39.4 \%$ in non-oil exports and of (-) $66.4 \%$ in oil companies. Within non-oil exports, those directed to the United States fell at an annual rate of (-) $40.7 \%$ and those channeled to the rest of the world did so by (-) 33.4 percent.

With figures adjusted for seasonality, in the fourth month of 2020, total merchandise exports reported a monthly reduction of (-) $37.67 \%$, which was the result of declines of (-) $37.54 \%$ in non-oil exports and of (-) $41.18 \%$ in oil companies (INEGI, 2020).

\section{Imports}

Imports are the transport of goods and services from abroad, which are acquired by a country to distribute them within it. Imports can be any product or service received within the border of a national state for commercial purposes. Imports allow economic agents to acquire products that are not produced in their country, cheaper, or of higher quality, benefiting them as consumers. Importation is when a country buys products from another country.

The value of merchandise imports in April of this year was 26,472 million dollars, an amount that implied an annual decrease of (-) $30.5 \%$; This figure was a reflection of decreases of (-) $27.6 \%$ in non-oil imports and of (-) $53 \%$ in oil companies. When considering imports by type of good, annual variations of (-) $46.5 \%$ were observed in imports of consumer goods, of (-) $28.1 \%$ in those of intermediate-use goods and of (-) $26.7 \%$ in those of capital goods.

With series adjusted for seasonality, total imports showed a monthly drop of (-) $21.93 \%$, which was derived from decreases of (-) $20.42 \%$ in non-oil imports and of (-) $36.56 \%$ in oil companies. By type of good, there were monthly decreases of (-) $33.34 \%$ in imports of consumer goods, of (-) $21.61 \%$ in those of intermediate-use goods and of (-) $7.35 \%$ in those of capital goods (INEGI, 2020).

\section{COVID-19 environment and its impact on foreign trade}

The coronavirus is a family of viruses that cause illness - from the common cold to more serious respiratory illnesses - and circulate between humans and animals. In this case, it is SARSCOV2. It appeared in China last December and causes a disease called COVID-19, which spread throughout the world and was declared a global pandemic by the World Health Organization.

As COVID-19 spreads rapidly around the world, and countries take steps to address the crisis, the health-related consequences are relevant, but also its impact on the economy and potential legal implications for organizations. 
With clearly foreseeable monetary repercussions, below; Some common scenarios are examined from the perspective of the legislation in Mexico, in order to determine the impact of COVID-19 and, even more importantly, provide elements to adopt a resilient and responsive position to the present and future threats that this situation could generate in various areas, including foreign trade (KPMG, 2020).

\section{International trade aspects}

The potential delay in the merchandise dispatch process could imply an increase in storage and handling costs. These aspects must be reevaluated with the suppliers in accordance with the applicable commercial terms, that is, companies with foreign trade operations will continue to receive the Datastage and may request its renewal after contingency measures (KPMG, 2020).

\section{Companies with foreign trade in Guanajuato}

In Guanajuato, companies are thinking big by joining the demand of global markets; Until October of this year, approximately 44 companies have joined the internationalization of their products.

Currently there are more than one thousand one hundred companies that have seen in exports a way to diversify their market, create new sources of employment and economic development for the community; in addition to making known that Guanajuato has a quality exportable offer to have a presence in 120 countries.

These companies are located in the municipalities of Salamanca, San Francisco del Rincón, Moroleón, Dolores Hidalgo, Celaya, Yuriria, Silao, Irapuato and Purísima del Rincón; and they belong to sectors such as auto parts automotive, agro-food, textiles and clothing, metal - mechanics, footwear, chemical products, hides and skins, construction, among other industries.

During this year, state companies have bet on Asian, European and Latin American markets with the firm objective of continuing to promote what was done in Guanajuato (COFOCE, 2020).

\section{Complications that COVID-19 brings in companies with foreign trade}

The impact that the pandemic generates on companies is reflected in the short and long term, such as (LegalToday, 2020):

- Travel restrictions and quarantines affecting hundreds of millions of people have left factories short of labor and parts, disrupting just-in-time supply chains and triggering sales warnings in the tech, automotive, goods industries. consumer, pharmaceutical and others.

- Commodity prices have declined in response to a drop in China's consumption of raw materials, and producers are considering cutting production.

Mobility and job disruptions have led to sharp declines in Chinese consumption, squeezing multinational companies in various sectors, including aviation, overseas education, infrastructure, tourism, entertainment, hospitality, electronics, consumer goods and luxury.

\section{Methodology to be developed}

Through an exploratory study (review of the literature and the study of the state of the art), secondary sources were obtained between reports from official pages of the Mexican government itself and INEGI, as well as journalistic notes from experts in foreign trade and documents related to the topic. The methodology is based on a research approach mainly based on the constructivist paradigm, with qualitative data that provide information that will contribute to future research.

\section{Results}

In this project, it was outlined, how the COVID19 has generated a great impact within foreign trade; where it was announced that this year 2020 has drastically affected the rate of real income from supplies of goods and services which decreased (-) $18.2 \%$, in addition to indicating a trade deficit of (-) 2.416 million dollars, balance that is compared with the deficit of (-) 4.643 million dollars obtained in the same month of 2019. 
On the other hand, it is announced that, within the imports during the month of January of last year, the amount of merchandise imports reached 36.069 million dollars, which implied an annual decline of (-) 3.2 percent. This figure originated from decreases of (-) $3.6 \%$ in non-oil imports and of (-) $0.4 \%$ in oil imports, generating a trade surplus of 5.547 million dollars in foreign trade in June 2020, this balance is compared to the surplus of 2,541 million dollars obtained in the same month of 2019. In the first six months of this year, the trade balance presented a surplus of 2,659 million dollars.

It was also announced that, within exports, in the sixth month of this year, the value of merchandise exports reached 33,076 million dollars, a figure made up of 31,818 million dollars of non-oil exports and 1,258 million dollars of oil companies, achieving that the value of merchandise imports in June 2020 was 27.53 billion dollars, an amount that implied an annual variation of (-) 22.2 percent. This figure was a reflection of decreases of (-) $18.2 \%$ in non-oil imports and (-) $55.4 \%$ in oil companies.

The World Trade Organization (WTO) forecasts that freight shipments will fall by up to $32 \%$ this year, mainly affecting the value chains of electronic products and the automotive industry in Asia and North America. In addition, Mexico's trade balance registered a deficit of (-) \$ 2,146 million dollars in January 2020. Oil, extractive and manufacturing exports increased, in line with our forecasts. The foreign trade balance was negative despite a lower flow of imports.

Likewise, a deficit of (-) $\$ 3.5$ billion dollars is estimated in the 2020 trade balance, this without counting the GDP growth for this year $(0.9 \%$ at an annual rate). On the other hand, it was announced that exports in February in Mexico decreased by 1,369 million dollars, due to the effects derived from the effects on the supply of inputs and components imported from China.
Therefore, the objective of knowing the impact that has been generated in the establishments with foreign trade operations derived from the COVID-19 contingency is fulfilled, counting on the information in general of the companies with foreign trade through a documentary investigation, both from primary and secondary sources and obtaining the results focused on the companies established in the state of Guanajuato, through the synthesis and analysis of the data obtained.

\section{Conclusions}

Today there are various issues that affect foreign trade worldwide, however, it is relevant to analyze the impact that the Covid-19 pandemic has caused economically within Mexican companies, and especially Guanajuato. This is not only reflected in the drop in imports, but also in the drop in investment by companies in the State.

Although in the first semester of 2020 a national surplus was obtained, even exceeding the January-June semester of last year, this does not mean growth in foreign trade; as there are circumstances that generate this situation, such as, for example, the depreciation of the Mexican peso.

On the other hand, the decrease in staff at the beginning of the year (2020) in establishments with an IMMEX program was announced, which presented a fall of (-) $0.3 \%$ during January of this year compared to the immediately previous month, this according to the type of establishment in which they work, in non-manufacturers (which carry out activities related to agriculture, fishing, commerce and services) decreased (-) $1.1 \%$ and in manufacturers (-) $0.2 \%$ at monthly rate. And ending the month of May with a decrease of (-) $1.9 \%$ in employed personnel in establishments with an IMMEX program. This according to the type of establishment in which they work, within the manufacturers there was a decrease of (-) $2.2 \%$, while in the non-manufacturers (which carry out activities related to agriculture, fishing, commerce and services) increased $0.7 \%$ at monthly rate.

Other factors that have caused and affected companies that practice foreign trade is the delay in the process of dispatching goods, which implied an increase in storage and handling costs.

CARMONA-GARCÍA, Nélida, RAMÍREZ-BARAJAS, Alejandro and ALMANZA-SERRANO, Ma. Leticia. The context of the impact of the COVID-19 contingency in establishments with foreign trade operations. RINOE Journal- International Economy. 2020 
Suppliers will have to analyze the necessary measures that from this contingency will have to consider in their operations and will form part of the applicable commercial terms.

Mexico will have to focus on concentrating its efforts on continuing to maintain and increase exports, since they are an important part of GDP, since of the 65\% that foreign trade represents, $30 \%$ refers to exports; they must also increase imports and encourage foreign investment. A relevant fact in this regard is to consider other markets, as recent data confirm the increase in exports by $10 \%$, where $82 \%$ have had good results when exporting to the African, Middle Eastern and European markets.

Therefore, it is concluded that the pandemic achieved great changes whereby, instead of taking it as an economic strike, Mexicans quickly took it as an opportunity to create micro-businesses, taking advantage of the changes in the way in which countries relate to each other. and in how governments face the problem day by day. International trade cannot be stopped, as it is part of an activity that determines the survival of world economies and without which we could not conceive of today's life. In this way, it is expected that in the following years the products will be exported to different countries, generating increased wealth within Mexico.

\section{References}

COFOCE. (2020). Empresas en Guanajuato. Obtained from https://cofece.guanajuato.gob.mx/tag/empresas/

Derecho, L. (2020). Comercio Mexicano en General. Obtained from https://mexico.leyderecho.org/empresas-decomercio-exterior/

Gobierno Federal-Economía. (2020). O Obtained from https://www.gob.mx/

Guanajuato. (2019). Comercio exterior empresas. Obtained from https://guanajuatoestado.infoisinfo.com.mx/

Importación, E. (2019). Comercio Exterior en las Empresas Mexicanas. Obtained from https://paqueteriahouston.com
INEGI. (2020). Balanza Comercial. Obtained from https://www.inegi.org.mx

INEGI. (2020). Comercio Exterior. Obtained from https://www.inegi.org.mx/datos/?t=0030

INEGI. (2020). Exportaciones e Importaciones. Obtained from https://www.inegi.org.mx/

Invex. (2020). Balanza Comercial. Obtained from

https://tusociofinanciero.mx/2020/02/balanzacomercial-enero-2020/

KPMG. (2020). Impacto legal para las empresas de México. Obtenido de https://home.kpmg

LegalToday. (2020). Consecuencias del Covid19 para las empresas. Obtained from www.legaltoday.com

Logística. (2020). Empresas comercio exterior en México. Obtained from http://www.logisticamx.enfasis.com

TMEC. (2020). Motor de Recuperación Económica para Guanajuato. Guanajuato.

Valencia, U. d. (2013). Obtained from https://www.uv.es/bellochc/logopedia/NRTLog o1.wiki?1 